\title{
SEPARAÇÃo de PODERES, EXECUTIVO UNITÁRIO E ESTADO ADMINISTRATIVO NO BRASIL
}

SÉRGIO GUERRA ${ }^{\dagger}$

\section{UM DOSSIÊ SOBRE ESTADO ADMINISTRATIVO}

RESUMO: A França adotou o modelo de governança executiva de forma hierárquica e piramidal (Executivo Unitário), influenciando o sistema tripartite brasileiro e a atuação do Chefe do Poder Executivo. Os Estados Unidos da América estruturaram-se sob a forma de federação presidencialista, inspirando o Brasil republicano (1891). A burocracia estadunidense foi estruturada por meio de agências externas ao Poder Executivo, formando o Estado Administrativo. Pretende-se neste artigo investigar o surgimento e a evolução do modelo de Estado Administrativo norte-americano e se houve influência desse modelo na burocracia brasileira.

\footnotetext{
† Pós-Doutor (Visiting Researcher, Yale Law School), Doutor e Mestre em Direito. PósDoutor em Administração Pública. Professor Titular de Direito Administrativo, ViceDiretor de Ensino, Pesquisa e Pós-Graduação e Coordenador do Mestrado em Direito da Regulação da FGV Direito Rio. Editor da Revista de Direito Administrativo RDA. Coordenador Geral do Curso Internacional Business Law da University of California - Irvine. Embaixador da Yale University no Brasil. Vogal da Comissão de Arbitragem e Árbitro da Câmara FGV de Mediação e Arbitragem. Árbitro da Câmara de Arbitragem da Federação da Indústria do Paraná e do Centro Brasileiro de Mediação e Arbitragem - CBMA. Consultor jurídico da Comissão de Direito Administrativo da OAB/RJ. Parte desse estudo foi publicado em GUERRA, Sérgio. Aperfeiçoando a regulação brasileira por agências: quais lições podem ser extraídas do sesquicentenário modelo norte-americano. In: Sérgio Guerra (Org.). Teoria do Estado Regulador. Curitiba: Juruá, 2015, p. 13-106.
} 
Palavras-Chave: Separação de Poderes; Executivo Unitário; Agências.

\begin{abstract}
France adopted the model of executive governance in a hierarchical and pyramidal way (Unitary Executive), influencing the Brazilian separation of powers system and the performance of the President. The United States of America was structured in the form of a federation, inspiring Brazilian republican (1891). The US bureaucracy was structured through independent agencies external to the Executive Branch, forming the Administrative State. This article intends to investigate the emergence and evolution of the US Administrative State model and whether this model had influence or not in the Brazilian bureaucracy.
\end{abstract}

KEYWORDS: Separation of Powers; Unitary Executive; Agencies. 
SUMÁRIO:

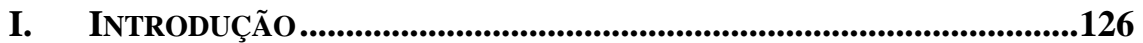

II. DESENVOLVIMENTO DO ESTADO ADMINISTRATIVO NORTE-AMERICANO NO SÉCULO XIX .......................................129

III. EXPANSÃO DO ESTADO ADMINISTRATIVO ESTADUNIDENSE

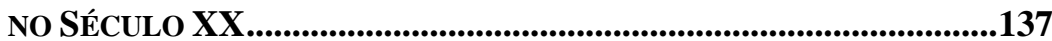

IV. IMPLEMENTOU-SE UM ESTADO ADMINISTRATIVO NO BRASIL PRÉ-CONSTITUIÇÃO DE 1988? ..............................................140

V. 1995: Plano Diretor da REFORMA do ESTADO E BUSCA PELO ESTADO ADMINISTRATIVO...............................................144

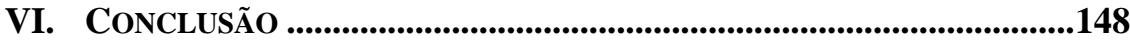

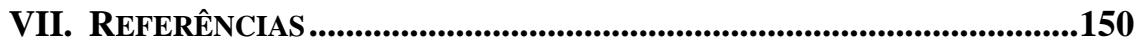

TABLE OF CONTENTS:

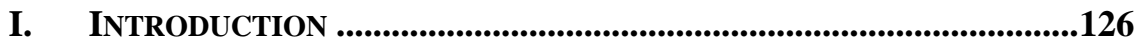

II. DEVELOPMENTS ON THE AMERICAN ADMINISTRATIVE STATE ON THE 19TH CENTURY.................................................129

III. EXPANSION OF THE AMERICAN ADMINISTRATIVE STATE ON THE 20TH CENTURY 137

IV. WAS AN ADMINISTRATIVE STATE IMPLEMENTED IN BRAZIL BEFORE DE CONSTITUTION OF 1988? 140

V. 1995: STATE Reform MASTER PLAN AND THE CHASE FOR THE ADMINISTRATIVE STATE ...................................................144

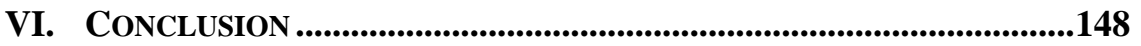

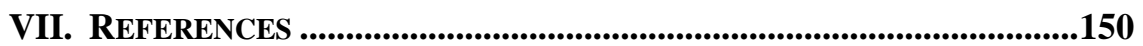




\section{INTRODUÇÃO}

O estudo do direito administrativo, no Brasil, foi formalmente autorizado pelo Imperador Dom Pedro II em 1851 e, em 1857, foi editado o primeiro livro de direito administrativo nacional por Vicente Pereira do Rego. ${ }^{1}$ Com poucas obras sobre o tema ${ }^{2}$, o livro de Antônio Joaquim Ribas $^{3}$, de 1866, foi o escolhido e formalmente aprovado pelo Imperador para uso nas Faculdades de Direito de São Paulo e Recife.

Pela leitura daquelas obras constata-se que a doutrina nacional daquele século foi amplamente influenciada pelo direito administrativo francês, definindo-o como sendo um conjunto de condições necessárias à conformação da estrutura burocrática governamental para a execução das regras (via regulamento) criadas pelo Poder Legislativo (lei).

A organização da máquina administrativa do Estado tinha características de unidade, centralização e uniformidade, sob um viés direcionado à manutenção do funcionamento dos serviços prestados pelo Estado e posição privilegiada em relação ao cidadão, então denominado súdito ${ }^{4}$ e, depois, administrado.

Como ponto central daquela estrutura destacava-se a superioridade do interesse público - e da Administração Pública - sobre o interesse

${ }^{1}$ REGO, Vicente Pereira do. Elementos de Direito Administrativo Brasileiro. Recife, PE: Typographia Universal, 1857.

2 É o caso da obra publicada em 1859, sob a influência gaulesa, de autoria de Veiga Cabral e do livro de Visconde do Uruguay. Cf. VEIGA CABRAL, Prudêncio Giraldes Tavares da. Direito Administrativo Brasileiro. Rio de Janeiro, RJ: Laemmert, 1859; e URUGUAY, Paulino José Soares de Souza, Visconde do. Ensaio sobre o Direito Administrativo. Rio de Janeiro, RJ: Typographia Nacional, 1862.

${ }^{3}$ RIBAS, Antonio Joaquim. Direito Administrativo Brasileiro. Rio de Janeiro, RJ: F.L. Pinto \& C., Livreiros-Editores, 1866, p. 2.

${ }^{4}$ Preâmbulo da Constituição do Império (1824): “Dom Pedro Primeiro, por graça de Deus, e unânime aclamação do povo, Imperador Constitucional e Defensor Perpétuo do Brasil: Fazemos saber a todos os nossos súditos que, tendo-nos requerido os povos deste Império, juntos em câmaras, que nós quanto antes jurássemos e fizéssemos jurar o projeto de Constituição, que havíamos oferecido às suas observações para serem depois presentes à nova Assembléia Constituinte, mostrando o grande desejo que tinham de que ele se observasse já como Constituição do Império, por lhes merecer a mais plena aprovação, e dele esperarem a sua individual e geral felicidade política: Nós juramos o sobredito projeto para o observarmos e fazermos observar, como Constituição, que de ora em diante fica sendo deste Império, a qual é do teor seguinte: $[\ldots]^{\prime \prime}$. 
privado, o princípio da legalidade, os serviços públicos (cuja teoria se desenvolveu, no início do século XX, pela Escola de Bordeaux) e o poder discricionário. Dessa premissa adveio o regime administrativo diferenciado, compreendendo as prerrogativas da Administração Pública em relação ao setor privado: poder de polícia, espécies de propriedade, de contratos (cláusulas exorbitantes do direito civil) e de responsabilidade.

Mas a influência francesa não atingiu apenas o Direito Administrativo sob a ótica científica. A estruturação da máquina burocrática também se deu, como naquele país europeu, de forma piramidal, napoleônica; isto é, centralizada na figura do Chefe do Poder Executivo (Executivo Unitário) sob a teoria tripartite da separação de poderes (Legislativo, Executivo e Judiciário).

Tanto aqui quanto lá adotou-se o princípio do Executivo Unitário, de modo a prevalecer o regime hierárquico entre os órgãos executivos, concentrando-se o poder no vértice da pirâmide.

De outro lado, o constitucionalismo brasileiro inspirou-se no sistema estadunidense. Na estrutura pensada pelos Framers, quanto ao poder e aos mecanismos de seu exercício, a pedra angular do sistema de garantias constitucionais também foi ancorado no princípio da separação tripartite de poderes (separation of powers).

A Constituição estadunidense, como a francesa, também definiu o poder estatal entre três estruturas: o Poder Legislativo (Legislative branch), que cria as leis, o Poder Executivo (Executive branch), que executa as leis, e o Poder Judiciário (Judiciary branch), que interpreta e faz cumprir as leis.

Nesse quadro, o modelo de governança executiva dos Estados Unidos da América trilhou em sentido diverso ao francês. Quando os Framers, que desenharam o modelo constitucional estadunidense no final do século XVIII, foram decidir quais seriam os poderes $e$ as responsabilidades que caberiam ao Executivo houve influência (negativa) do relacionamento das antigas colônias com o governo britânico, então sob o poder do Rei George William Frederick (George III).

Considerando os abusos perpetrados pelo monarca inglês, que governou por quase sessenta anos, os Founding fathers da Constituição americana decidiram que os poderes detidos pelo presidente da nova república deveriam ser restritos. ${ }^{5}$ Seria o "governo das leis", e não o "governo dos homens".

De outro lado, os Framers também tinham a compreensão de que esses poderes deveriam ser suficientes para que o Chefe do Poder Executivo

${ }^{5}$ MOSHER. Frederick. Basic documents of American public administration: 17761950. New York, NY: Holmes \& Meier Publishers, Inc. 1976, p. 5. 
pudesse conduzir a política externa, governar de forma eficiente, visando a conter as disputas entre os estados da nova federação. $O$ desafio envolvia ter um Poder Executivo dotado de ferramentas que favorecessem a governabilidade, e, de outro lado, que não permitisse o arbítrio e a tirania tão repudiados pelos colonizados. Assim é que os pais fundadores da ordem constitucional norte-americana estruturam o poder executivo no artigo II da Constituição, onde pode-se constatar que os poderes são específicos, relativamente limitados, e descritos sob uma linguagem extremamente vaga.

De fato, a Constituição norte-americana procurou trazer algumas contenções das funções detidas pelo Poder Executivo. Basicamente, o Presidente da República norte-americano exerce a posição de comandante-em-chefe (Commander in Chief) das forças armadas, e detém competência para conceder perdões, firmar tratados, nomear embaixadores, juízes da Suprema Corte e outros oficiais do governo. Em termos gerais, e ainda que não claramente definido no texto constitucional sobre como deveria fazer, nem, tampouco, com que estrutura deveria contar para alcançar esse objetivo, o Presidente da República é competente para garantir que as leis, criadas pelo Poder Legislativo (Legislative branch), sejam fielmente executadas.

Considerando que a Constituição Federal norte-americana não disciplinou a estrutura do Poder Executivo para o desempenho de suas funções, essa questão foi desenvolvendo-se ao longo do tempo de forma diversa ao ocorrido na França. Construiu-se, pouco a pouco, um modelo de governança que denominou-se Estado Administrativo (Administrative State), também representado na doutrina pelas expressões: bureaucratic state, capitalist state, corportate state, posindustrial state, regulatory state e welfare state ${ }^{6}$ contrapondo-se ao princípio do Executivo Unitário.

O Estado Administrativo, portanto, é uma concepção tipicamente norte-americana e estruturada por meio de agências (executivas e reguladoras) externas ao Poder Executivo, que compõem a burocracia estatal estadunidense.

Diante do exposto, pretende-se investigar neste artigo a evolução do típico Estado Administrativo, surgido nos Estados Unidos da América, e se houve influência desse modelo na burocracia brasileira ao longo do seu período republicano. Buscar-se-á respostas sobre as indagações: como o Estado Administrativo dos Estados Unidos da América, que constitui

${ }^{6}$ Cf. SKOWRONEK, Stephen. Building a New American State: the Expansion of National Administrative Capacities, 1877-1920. New York, NY: Cambridge University Press, 1982, p. 3. 
para alguns um "quarto poder" (headless fourth branch)7, se desenvolveu e foi admitido no sistema constitucional tripartite de poderes? O Brasil, no período pré-democrático (até 1988), para além das três funções clássicas (Legislativa, Executiva e Jurisdicional), implantou um sistema próximo ao Estado Administrativo? Após a Reforma do Estado, na década de 90, pode-se afirmar que o Brasil adotou esse sistema de governança?

Para essa pesquisa será adotado o método dedutivo partindo-se de argumentos gerais para argumentos particulares, trazendo bases históricas sobre a administração pública estadunidense e brasileira para apresentar as suas conclusões.

\section{DesenVolvimento do Estado AdMinistrativo NORTE- AMERICANO NO SÉCULO XIX}

No começo da nova república os primeiros presidentes norteamericanos contavam com poucos órgãos ou agentes para assessorá-los, haja vista que a Constituição não continha - nem contém até hoje disposição específica quanto à estrutura de apoio presidencial. Esse cenário foi sendo alterado, passo a passo, por meio de vários fatos que marcaram a transformação dos Estados Unidos. ${ }^{8}$

A doutrina de separação de poderes não era clara sobre quem deveria exercer atividades administrativas, se o legislativo ou o executivo:

The doctrine was not clear - and is still not clear - as to the powers and responsibilities of the executive and the legislative branches with respect to the administration of public programs. During much of the nineteenth century, and with the exceptions to the Jackson administration and in wartime, the balanced tended in direction of the legislative and away from the executive in both the nation and the states, thus inhibiting the development of

${ }^{7}$ De acordo com a crítica desfavorável ao modelo, as agências acabaram por constituir um quarto poder, congregando, em uma única entidade, as três funções estatais que, concentradas, superam aquelas constitucionalmente atribuídas isoladamente aos três poderes tradicionais. Essa afirmação constou do relatório produzido pelo Brownlow Committee, criado pelo Presidente Roosevelt em 1937, que sustentou que as agências independentes deveriam ser extintas com a transferência de suas funções para as agências executivas.

8 Uma detalhada pesquisa sobre essas transformações está em SKOWRONEK, Stephen. Building a New American State: the Expansion of National Administrative Capacities, 1877-1920. New York, NY: Cambridge University Press, 1982. 
integrated, coordinated, and unified administrations. ${ }^{9}$

Para o exercício das atividades administrativas foram criadas entidades conhecidas como "agências". As primeiras agências foram criadas a nível estadual para auxiliar o Poder Legislativo, seja disponibilizando informações técnicas, seja para colaborar em algum assunto específico.

Em 1832, o Estado de Connecticut criou uma comissão especial, tornando-a permanente em 1849 e Rhode Island criou uma modesta agência, que visava encorajar empresas rivais a trabalhar de forma conjunta ${ }^{10}$. Outros Estados também criaram agências, a exemplo dos Estados de New Hampshire e Rhode Island, em 1844; Estado de New York, em 1850 e Estado de Vermont, em 1855: ${ }^{11}$

Viewed generally, therefor, these earliest commissions were occasional, and created for the randling of special or ad hoc situations. They had a variety of functions, but mainly they were to serve as fact-finding agencies for the legislature and to handle tasks which that body had undertaken and in which it had failed. They were looked upon as agents of the legislature and not in any sense as part of the executive branch. ${ }^{12}$

Depois dessa fase, entre 1869 e 1887, surgiram as agências estaduais para regular o serviço ferroviário, a mais importante atividade econômica naquele momento da história estadunidense. As primeiras agências, nesse formato, foram criadas nos estados da Nova Inglaterra, com a chegada da primeira agência no Estado de Massachusetts em 1869 e, depois, Colorado, Connecticut, Iowa, Kentucky, Maine, Michigan, Nebraska, New York, Ohio, Rhode Island, Vermont, Virginia e Wisconsin. ${ }^{13}$

${ }^{9}$ MOSHER. Frederick. Basic documents of American public administration: 17761950. New York, NY: Holmes \& Meier Publishers, Inc. 1976, p. 44.

${ }^{10}$ Cf. McCRAW, Thomas, et al. Prophets of Regulation: Charles Francis Adams, Louis

D. Brandeis, James M. Landis, Alfred E. Kahn. Cambridge, MA: Belknap Press of Harvard University Press, 1984, p. 17.

${ }^{11}$ Cf. CUSHMAN, Robert. The Independent Regulatory Commissions. New York, NY: Octagon Books, 1972, p. 23.

${ }_{12}$ Cf. CUSHMAN, Robert. The Independent Regulatory Commissions. New York, NY: Octagon Books, 1972.

${ }^{13}$ Os detalhes sobre essas agências estaduais podem ser conferidos em CUSHMAN, Robert. The Independent Regulatory Commissions. New York, NY: Octagon Books, 
Em 1871, o estado de Illinois criou uma agência dotada de vastos poderes, de modo que a agência poderia exercer intenso controle sobre as atividades ferroviárias. Esse modelo, seguido por outros Estados (Alabama, California, Georgia, Kansas, Minnesota, Mississippi, New Hampshire e South Caroline), é considerado pela doutrina como sendo um importante avanço na técnica de regulação do sistema ferroviário estadual, formando a base da futura regulação no âmbito nacional.

A modalidade de regulação estatal forte (strong commission), com seus poderes, foi muito questionada, sendo a sua constitucionalidade submetida em vários casos à Suprema Corte norte-americana. Merece destaque o caso julgado pela Suprema Corte, em 1877, denominado Munn v. Illinois, ${ }^{14}$ que apreciou o questionamento sobre as tarifas que impactavam as atividades agrícolas.

Esse caso é citado como o remarkable case que permitiu, aos estados da federação, regular certos negócios dentro de suas fronteiras, incluindo as ferrovias. Por isso, é considerado um importante precedente após a guerra civil americana a favor da corrente progressista defensora da função estatal de regulação das atividades privadas.

Nesse julgamento o Chef Justice Waite decidiu que os estados eram detentores de competência para regular o uso da propriedade privada quando tal regulamentação tornava-se necessária para o bem público. Waite buscou fundamento na doutrina do direito romano ao sustentar que "quando a propriedade é afetada com um interesse público, deixa de ser apenas privati juris". É assinalável que Munn foi um dos seis casos, os chamados casos Granger, ${ }^{15}$ decididos pela Suprema Corte dos Estados

1972, p. 25. Em nossas pesquisas, não encontramos certa precisão na ordem cronológica de criação das agências estaduais.

${ }^{14}$ Munn v. Illinois, 94 U.S. 113 (1876).

${ }^{15}$ Conhecido como Granger Movement, e que levou a Suprema Corte a proferir importantes decisões sobre a intervenção estatal, tratava-se de uma associação de pecuaristas fundada em 1867 para promover métodos de agricultura, bem como para promover o desenvolvimento das necessidades sociais e econômicas dos agricultores nos Estados Unidos. Começou em 1886 com Oliver Hudson Kelley, funcionário do Departamento de Agricultura. A princípio, apenas o estado natal de Kelley, Minnesota, parecia sensível aos movimentos Granger, mas em 1870 nove estados aderiram. Em meados da década de 1870 quase todos os estados tinham pelo menos um Grange, e a associação nacional chegou perto de 800.000 membros. O que atraiu a maioria dos agricultores ao movimento Granger foi a necessidade de uma ação unificada contra as ferrovias monopolistas e elevadores de grãos (muitas vezes de propriedade das ferrovias) que cobravam taxas exorbitantes para manusear e transportar as colheitas dos agricultores e outros produtos agrícolas. Sobre o tema, cf.

3 JOURNAL OF INSTITUTIONAL STUDIES 1 (2017) 
Unidos a favor dos Estados, todos ao mesmo tempo e no mesmo sentido. Releva destacar, ainda, o Peik case, ${ }^{16}$ julgado pela Suprema Corte em 1877, em que decidiu-se que os Estados só poderiam regular o sistema ferroviário interestadual dentro das suas fronteiras, prejudicando a efetividade da regulação estadual. Assim decidiu a Suprema Corte:

(1) This Court follows the Supreme Court of Illinois in holding that the statute of Illinois must be construed to include a transportation of goods under one contract and by one voyage from the interior of the State of Illinois to New York. (2) This Court holds further that such a transportation is 'commerce among the states' even as to that part of the voyage which lies within the State of Illinois, while it is not denied that there may be a transportation of goods which is begun and ended within its limits, and disconnected with any carriage outside of the state, which is not commerce among the states. (3) The latter is subject to regulation by the state, and the statute of Illinois is valid as applied to it. But the former is national in its character, and its regulation is confided to Congress exclusively, by that clause of the Constitution which empowers it to regulate commerce among the states. (4) The cases of Munn v. Illinois, 94 U.S. 113; Chicago v. Burlington \& Quincy Railroad Co. v. Iowa, 94 U.S. 155, and Peik v. Chicago \& Northwestern Railway, 94 U.S. 164, examined in regard to this question, and held, in view of other cases decided near the same time, not to establish a contrary doctrine. (5) Notwithstanding what is there said, this Court holds now, and has never consciously held otherwise, that a statute of a state, intended to regulate or to tax or to impose any other restriction upon the transmission of persons or property or telegraphic messages from one state to another, is not within that class of legislation which the states may enact in the absence of legislation by Congress, and that such statutes are void even as to that part of such transmission which may be within the state. (6) It follows that the statute of Illinois, as construed by the supreme court of the state and as applied to the transaction under consideration, is forbidden by the Constitution of the United States, and the judgment of that court is reversed.

Outro caso de aguda relevância sobre a evolução tema, decidido pela Suprema Corte em 1886, ficou conhecido como Wabash case. ${ }^{17}$ Também,

SKOWRONEK, Stephen. Building a New American State: the Expansion of National Administrative Capacities, 1877-1920. New York, NY: Cambridge University Press, 1982, p. 125.

${ }_{16}$ Peik v. Chicago \& Northwestern Railway Co., 94 U.S. 164 (1876).

17 Wabash, St. Louis \& Pacific Railway Co. v. Illinois, 118 U.S. 557 (1886). 
referindo-se aos limites da intervenção no nível estadual, foi decido que os estados passariam a ser impedidos de regular o comércio interestadual, de modo que somente o governo federal poderia fazê-lo:

The Wabash decision injected into the picture what someone has called the categorial imperative. Its precise and immediate effect upon Congressional leaders remains in doubt; but it made federal regulation clearly imperative, and the Interstate Commerce Act of 1887 was passed within a few months. ${ }^{18}$

Nesse contexto, e com a decisão no caso Wabash dando suporte ao projeto de lei em tramitação (Cullom's bill), ${ }^{19}$ em 1887, por meio do Interstate Commerce Act, o Congresso criou, no âmbito federal, a primeira agência reguladora "moderna" 20 , inaugurando uma nova era do Estado Administrativo. Essa lei foi promulgada pelo Congresso para regular o transporte ferroviário interestadual, de pessoas ou bens.

No século XIX, começaram a surgir os monopólios naturais, ${ }^{21}$ isto é, aqueles setores de utilidade pública que não suportam, de forma eficiente, a participação de mais de uma indústria. ${ }^{22}$ Registre-se, ainda, a forte industrialização, os trusts, ${ }^{23}$ os cartéis, a forte concentração de

${ }^{18}$ Cf. McCRAW, Thomas, et al. Prophets of Regulation: Charles Francis Adams, Louis D. Brandeis, James M. Landis, Alfred E. Kahn. Cambridge, MA: Belknap Press of Harvard University Press, 1984, p. 61.

${ }^{19}$ Cf. McCRAW, Thomas, et al. Prophets of Regulation: Charles Francis Adams, Louis D. Brandeis, James M. Landis, Alfred E. Kahn. Cambridge, MA: Belknap Press of Harvard University Press, 1984, p. 61.

${ }^{20}$ CASS, Ronald, et al. Administrative Law: cases and materials. $6^{a}$ ed. New York, NY: Wolters Kluwer Law \& Business, 2011, p. 3.

${ }^{21}$ Nesse sentido, BREYER, Stephen. Regulation and its Reform. Cambridge, MA: Harvard University Press, 1982, p. 15.

${ }^{22}$ Cf. PRIEST, George. The Origins of Utility Regulation and the "Theories of Regulation" Debate. Journal of Law \& Economics, Vol. 36, 1, 1993, p. 289-323.

${ }^{23}$ Trusts eram as empresas que possuíam as seguintes características: larga escala e gestão centralizada. Exemplos: Standard Oil, American Tobacco e United States Steel. Cf. McCRAW, Thomas, et al. Prophets of Regulation: Charles Francis Adams, Louis D. Brandeis, James M. Landis, Alfred E. Kahn. Cambridge, MA: Belknap Press of Harvard University Press, 1984, p. 65. Segundo o autor: "The trust movement - that is, the powerful tendency of businessmen to combine with their competitors in association. This was the problem of periodic industrial overcapacity, tied to the boomand-bust cycles of the late nineteenth century". McCRAW, Thomas, et al. Prophets of 
riquezas, a corrupção na máquina estatal e os problemas sociais daí decorrentes.

Em 1890 foi editada uma nova lei contra os cartéis (the Sherman Act), que formalizava a hostilidade da common law contra essa prática e forçava o Departamento de Justiça a agir, ativamente, contra essas associações. ${ }^{24}$ Por meio dessa lei, os contratos ou qualquer outra forma de combinação em forma de trust, ou conspiração para restringir o comércio entre os diversos estados ou com nações estrangeiras, foi declarada ilegal. Do mesmo modo, qualquer pessoa que monopolizasse, ou tentasse monopolizar, qualquer ramo da indústria ou do comércio entre os diversos estados ou com nações estrangeiras, seria considerada culpada.

Para a implementação dessas disposições legais, registre-se dois fatos. Em primeiro lugar, não foi criada uma agência para a fiscalização/regulação, e, em segundo, ocorrido cinco anos após a edição do Sherman Act, a Suprema Corte acabou por enfraquecer esse novo instituto. Numa decisão histórica, o tribunal estabeleceu um novo standard interpretativo denominado the rule of reason. Foi no caso United States v. E.C. Knight Company (1895), ${ }^{25}$ no qual o Tribunal decidiu que a American Sugar Refining Company, um dos outros réus no caso, não havia violado a lei apesar de controlar cerca de $98 \%$ de todo o refino de açúcar nos Estados Unidos:

The apparent clarity of the statutory language became lost in verbal uncertainties. Courts struggled with the meaning of such terms as 'restraint of trade' and 'monopolization'; and judge's opinions created a semantic confusion that persisted for years afterward. Soon the obvious ineffectiveness of early antitrust policy began to stimulate a new movement to do something more. ${ }^{26}$

Esses fatos da história norte-americana contribuíram para a expansão

Regulation: Charles Francis Adams, Louis D. Brandeis, James M. Landis, Alfred E.

Kahn. Cambridge, MA: Belknap Press of Harvard University Press, 1984.

${ }^{24}$ Cf. McCRAW, Thomas, et al. Prophets of Regulation: Charles Francis Adams, Louis

D. Brandeis, James M. Landis, Alfred E. Kahn. Cambridge, MA: Belknap Press of Harvard University Press, 1984, p. 68.

${ }_{25}$ United States v. E.C. Knight Co., 156 U.S. 1 (1895).

${ }^{26}$ McCRAW, Thomas, et al. Prophets of Regulation: Charles Francis Adams, Louis D.

Brandeis, James M. Landis, Alfred E. Kahn. Cambridge, MA: Belknap Press of Harvard University Press, 1984, p. 79. 
da burocracia ${ }^{27}$ e a forma de atuação governamental por meio do denominado Estado Administrativo. Em seu principal livro James Landis apresenta comentários sobre o surgimento do Estado Administrativo, estruturado por meio de agências. Segundo ele, a nomenclatura (administrative state) deveu-se ao direito administrativo francês pela aproximação da nova categoria processual das agências com o sistema de trâmite de litígios entre o governo e os cidadãos:

The insistence upon the compartmentalization of power along triadic line gave way in the nineteenth century to the exigencies of governance. Without too much political theory but with a keen sense of the practicalities of the situation, agencies were created whose functions embraced the three aspects of government. Rule-making, enforcement, and the disposition of competing claims made by contendies parties, were all intrusted to them. As the years passed, the process grew. These agencies, tribunals, and reule-making boards were for the sake of convenience distinguished from the existing governmental bureaucracies by terming them 'administrative'. The law the courts permitted them to make was named 'administrative law', so that now the process in all its component parts can be appropriately termed the 'administrative process'. The terminology, like the formulation of the doctrine of the separation of the powers, seems to have had a Garllic origin. [...] Because droit administrative concerned the disposition of claims between the government and individual, and because the major emphasis of our newer administrative agencies appeared to concern the same category of claims, a superficial similarity was present. ${ }^{28}$

Nas palavras de James Landis, um dos seus arquitetos ${ }^{29}$, o modelo de estado administrativo surgiu pela inadequação da forma tripartite clássica de exercício do poder do Estado (Legislativo, Executivo e Judiciário), para lidar com os complexos problemas modernos, ${ }^{30}$ a

${ }^{27}$ Cf. SKOWRONEK, Stephen. Building a New American State: the Expansion of

National Administrative Capacities, 1877-1920. New York, NY: Cambridge University Press, 1982, p. 4.

${ }^{28}$ LANDIS, James. The Administrative Process. New Haven, CT: Yale Univesity Press, 1938, p. 2-3.

${ }^{29}$ McCRAW, Thomas, et al. Prophets of Regulation: Charles Francis Adams, Louis D. Brandeis, James M. Landis, Alfred E. Kahn. Cambridge, MA: Belknap Press of Harvard University Press, 1984.

${ }^{30}$ LANDIS, James. The Administrative Process. New Haven, CT: Yale Univesity Press, 1938, p. 1. Nesse sentido, decidiu a Suprema Corte norte-americana no caso Mistretta $v$.

3 JOURNAL OF INSTITUTIONAL STUDIES 1 (2017) 
exemplo, como visto, do sistema de trusts. Ademais, as cidades ficaram superpovoadas, as condições sanitárias e de trabalho dos operários eram péssimas, aumentando o número de doentes.

Sob uma interpretação mais literal, o fundamento constitucional para a estruturação do Estado Administrativo seria o artigo I, seção 8 (The necessary-and-proper clause). ${ }^{31}$ Esse dispositivo constitucional estabelece que o Congresso é detentor de competência para editar todas as leis que sejam necessárias e adequadas para executar os poderes a ele assegurados pela Constituição Federal, e todos os outros poderes em qualquer departamento.

Mesmo com a linguagem ampla e vaga da Constituição, argumentase que os Framers, ao optar por consignar a denominada necessary-andproper clause, já identificavam a futura necessidade da criação de alguma entidade, como as agências. ${ }^{32}$ Seria uma nova função estatal, denominada "administrativa" ou "regulatória", diferente das demais funções previstas no texto constitucional (legislativa, executiva e judicial). ${ }^{33}$

United States, 488 U.S. 361 (1989): “Applying this 'intelligible principle' test to congressional delegations, our jurisprudence has been driven by a practical understanding that, in our increasingly complex society, replete with ever-changing and more technical problems, Congress simply cannot do its job absent an ability to delegate power under broad general directives."

${ }^{31}$ Constituição dos Estados Unidos da América: "Section 8. 1: The Congress shall have Power (...) 18: To make all Laws which shall be necessary and proper for carrying into Execution the foregoing Powers, and all other Powers vested by this Constitution in the Government of the United States, or in any Department or Officer thereof". Nesse sentido, CUSHMAN, Robert. The Independent Regulatory Commissions. New York, NY: Octagon Books, 1972, p. 425. Em sentido contrário, LAWSON, Gary. Limited Government, Unlimited Administration: Is it possible to restore Constitution? First Washington, DC: Heritage Foundation, 2009, p. 1-16.

${ }^{32}$ CUSHMAN, Robert. The Independent Regulatory Commissions. New York, NY: Octagon Books, 1972, p. 422-426. Ver posicionamento próximo em MOSHER.

Frederick. Basic documents of American public administration: 1776-1950. New York, NY: Holmes \& Meier Publishers, Inc. 1976, p. 5.

${ }^{33}$ Diversos fatores, portanto, levaram os Estados Unidos da América ao implemento dessa nova modalidade de atuação governamental que materializou a teoria do Administrative State: "Public regulation of business affairs developed as a reaction to the process of industrial and economic change that has drastically altered the shape of American society. Techonological advances increased the rate of industrialization, as well as the urbanization of the population. While have immigration in the latter part of the nineteenth century was absorbed throughout the country, the cities and the new 


\section{EXPANSÃO DO ESTADO ADMINISTRATIVO ESTADUNIDENSE NO SÉCULO XX}

O processo de expansão do Estado Administrativo deu-se no período progressista, em que o país experimentou forte prosperidade. Destaquese o desenvolvimento da aviação, indústria automobilística, rádios, filmes, energia elétrica e telefonia, alterando o perfil econômico nos Estados Unidos.

A entrada dos Estados Unidos na primeira guerra mundial provocou mudanças e marcou o fim da era progressista. Grandes desafios surgiram para o Estado com os problemas decorrentes da forte expansão do crédito, inclusive o mercado de ações, alcançando grandes altas posteriormente afetadas pela queda da Bolsa de Valores de Nova Iorque em 1929.

A crise decorrente da Grande Depressão (Great Depression), ocorrida na década de 1930, acabou por levar à criação de mais agências governamentais. Com efeito, em que pese a existência de entes reguladores desde o século XVIII, foi no Governo do Presidente Franklin D. Roosevelt, primo de Theodore Roosevelt, sob a forma de um programa conhecido como New Deal, em que o Poder Executivo e o Congresso estruturaram a máquina estatal para enfrentar os enormes e complexos problemas sociais e econômicos que o país enfrentava. ${ }^{34}$

O programa resultou na estruturação de uma burocracia federal, bem diferente do antigo modelo denominado spoil system, em que os cargos públicos eram preenchidos pelos partidos políticos vencedores das eleições. Roosevelt criou uma Comissão (Committe on Administrative Management), que ficou popularmente conhecida como Brownlow Committee, por ter sido comandada por Louis Brownlow. O trabalho consistia em analisar a organização do poder executivo e sugerir soluções para grandes problemas que afetavam a governança estatal. O relatório Brownlow, concluído em 1937, fez diversas recomendações, incluindo a criação de um órgão (The Executive Office of the President - EOP), que reunisse as atividades do poder executivo, tais como orçamento, eficiência, pessoal e planejamento.

industrial areas were the principal points of immigrants settlement." BERNSTEIN, Marver. Regulating Business by Independent Commission. Princeton, NJ: Princeton University Press, 1955, p.16.

${ }^{34}$ Cf. McCRAW, Thomas, et al. Prophets of Regulation: Charles Francis Adams, Louis D. Brandeis, James M. Landis, Alfred E. Kahn. Cambridge, MA: Belknap Press of Harvard University Press, 1984, p. 152. 
O Congresso rejeitou algumas propostas contidas no relatório Brownlow, mas aprovou a criação do EOP, por meio do Reorganization Act de abril de 1939. O principal benefício dessa inovação, trazida pelo relatório Brownlow, consistiu na estruturação de um órgão de apoio direto da presidência da república.

Foram criadas várias agências federais, para regular, por exemplo, valores mobiliários (1934), energia (1935), relações de trabalho (1935), transporte de cargas (1935), carvão (1937), aviação (1938) e gás natural (1938). ${ }^{35}$

Quando os Estados Unidos ingressaram na Segunda Guerra Mundial, mais agências foram criadas ou ampliadas para controlar a produção de bens, inclusive preços e racionamento. Nas décadas de 60 e 70 o Congresso norte-americano enveredou por uma nova fase denominada social regulation, visando combater a discriminação, fraudes ao consumidor, saúde, segurança e proteção ao meio ambiente. ${ }^{36} \mathrm{~A}$ ideia era oferecer oportunidades para as pessoas que, historicamente, foram desfavorecidas e marginalizadas ${ }^{37}$, sob a justificativa de "externalidades ou informações assimétricas". ${ }^{38}$ Essa fase é explicada por Stephen Breyer:

Beginning in the mid-1960s the number of federal regulatory agencies and the scope of regulatory activities vastly expanded. The federal government began to regulate oil prices and other aspects of energy production; to impose

35 "The explosion of regulatory legislation during the 1930s reflected something besides the economic crisis of that decade. It also represented a widespread popular conviction that the free market was hopeless flawed. The same premises that underlay the Keynesian revolution in macroeconomics during the 1930s - that government should take a hand, that expert public servants were more likely than business executives to choose the wise course - also applied to microeconomic regulation." McCRAW, Thomas, et al. Prophets of Regulation: Charles Francis Adams, Louis D. Brandeis, James M. Landis, Alfred E. Kahn. Cambridge, MA: Belknap Press of Harvard University Press, 1984, p. 210.

${ }^{36}$ Cf. SKOWRONEK, Stephen. Building a New American State: the Expansion of National Administrative Capacities, 1877-1920. New York, NY: Cambridge University Press, 1982, p. 17.

37 Várias críticas contra a atuação das agências foram apresentadas nessa fase por um dos "pais" da regulação estadunidense. Cf. LANDIS, James. Report on regulatory agencies to the president-elect: a report submitted to Sen. John F. Kennedy December 21, 1960. New Orleans, LA: Quid Pro Books, 2014. ${ }^{38}$ DUDLEY, Susan; BRITO, Jerry. Regulation: a Primer. $2^{\mathrm{a}}$ ed. Arlington, VA: The George Washington University, 2012, p. 78. 
significant controls upon environmental pollution; and to regulate the safety of the workplace, of the highway, and of consumer products. It increased regulatory protection of investors, including pension holders and commodities traders. ${ }^{39}$

A partir dos anos 70, e diante da crise econômica mundial, esse período se destaca pelo excessivo número de regras regulatórias, altamente complexas e detalhadas (microregulation) provocando um grande movimento contra os custos decorrentes da regulação.

Merecem destaque os estudos desenvolvidos pela Escola de Chicago, notadamente o artigo escrito por George Stigler, publicado em 1971, sustentando, com evidências empíricas, que a regulação é "conquistada" pela empresa, visando seu próprio benefício (controle do ingresso de rivais no setor, subsídios, fixação de preços etc.). Segundo Stigler, essa forma de atuação representa uma captura da agência pelos regulados, além de incrementar demasiadamente os custos para a sociedade. ${ }^{40}$

Releva destacar, ainda quanto à década de 70 , que houve uma forte crise, com grande impacto na economia norte-americana. Em 1973 o preço do petróleo disparou, houve uma queda no desenvolvimento tecnológico, constatou-se incremento das taxas de juros e a inflação acelerou. As empresas, que dependiam de aprovação regulatória para aumentar seus preços, começaram a sentir as perdas pela demora decorrente do complexo processo regulatório (regulatory lag). ${ }^{41}$ Também nesse momento houve grande popularidade das questões ambientais, sendo criada a Environmental Protection Agency - EPA, afetando as plantas industriais com o aumento de custos para a instalação de novos equipamentos de controle da poluição.

A partir de então, e diante de muitas pressões, a regulação perdeu importância fazendo com que o Congresso iniciasse um processo de redução do nível de atividade das agências. Esse movimento ficou conhecido como desregulação (deregulation), período em que foi desmobilizado parte do aparato calcado no modelo de agencificação

${ }^{39}$ BREYER, Stephen. Regulation and its Reform. Cambridge, MA: Harvard University Press, 1982, p. 1.

${ }^{40}$ STIGLER, George. The Theory of Economic Regulation. The Bell Journal of Economics and Management Science, Vol. 2, 1, 1971. As críticas a essa abordagem podem ser conferidas em POSNER, Richard. Theories of Economic Regulation. The Bell Journal of Economics and Management Science, Vol. 5, 2, 1974, p. 335-358.

${ }^{41}$ Cf. McCRAW, Thomas, et al. Prophets of Regulation: Charles Francis Adams, Louis D. Brandeis, James M. Landis, Alfred E. Kahn. Cambridge, MA: Belknap Press of Harvard University Press, 1984, p. 239. 
setorial. Houve, nessa fase, grande influência dos trabalhos publicados por Alfred Kahn, que se baseavam na teoria dos custos marginais (marginal-cost pricing). ${ }^{42}$ Os setores mais atingidos com o movimento de desregulação foram a aviação, o transporte de cargas e rodovias e, ironicamente, a ICC - primeira agência da nova era de regulação estatal federal - foi desativada em 1996.

Com esse histórico, pode-se constatar a consolidação do modelo de Estado Administrativo norte-americano no século XX.

\section{IMPLEMENTOU-SE UM ESTADO ADMINISTRATIVO NO BRASIL PRÉ-CONSTITUIÇÃO DE 1988?}

Se a máquina administrativa nacional - e o direito administrativo sofreram influências francesas, a República Federativa brasileira surgiu com a promulgação da Constituição Federal de 1891, fortemente influenciada pelo modelo estadunidense, federalista, e que também teve os seus poderes de Estado estruturados em um sistema tripartite: o Legislativo (com duas casas), o Executivo e o Judiciário, adotando-se, também, o presidencialismo.

Diante da concepção de Estado Administrativo estadunidense, indaga-se: e no Brasil? As influências do constitucionalismo norteamericanas foram absorvidas entre nós no campo burocrático? Adotamos, ainda que por certo tempo, o modelo de Estado Administrativo?

Como dito, na obra de Antonio Joaquim Ribas o autor apresenta a ideia chave de hierarquia e centralização da administração pública brasileira, sob a forma piramidal, próxima ao modelo francês e, portanto, diversa do modelo de separação do Poder Executivo do denominado "Poder Administrativo" estadunidense:

Não existe, pois, um poder administrativo distincto e independente do executivo. O poder administrativo, ou a administração, é o mesmo executivo - abstracção feita das suas funcções governamentaes - , diffundido pelas innumeras ramificações de seus funccionarios e empregados, desde o

${ }^{42}$ Cf. McCRAW, Thomas, et al. Prophets of Regulation: Charles Francis Adams, Louis

D. Brandeis, James M. Landis, Alfred E. Kahn. Cambridge, MA: Belknap Press of Harvard University Press, 1984, p. 228.

3 JOURNAL OF INSTITUTIONAL STUDIES 1 (2017) 
Monarcha, que é o seu Chefe, até os mais subalternos agentes. ${ }^{43}$

A concentração de poderes nas mãos do Chefe do Poder Executivo também apareceu de forma nítida três anos depois de promulgada a Constituição Federal de 1981, sendo editada a Lei no 221, de 20 de novembro, que positivou a base para o controle do "poder discricionário" exercido pelo Chefe do Poder Executivo, de acordo com teorias francesas que definiam os limites do controle judicial sobre os atos administrativos discricionários: “§ 9o b) A medida administrativa tomada em virtude de uma faculdade ou poder discricionario sómente será havida por illegal em razão da incompetencia da autoridade respectiva ou do excesso de poder."

A forte centralização se confirmou com Getulio Vargas, que chegou ao poder em 1930 quando assumiu a Presidência da República. $O$ ato que instituiu o Governo Provisório da República dos Estados Unidos do Brasil (Decreto № 19.398 de 11 de novembro de 1930), explicitou o poder discricionário da Chefia do Poder Executivo, levando-se, inclusive, a positivar o impedimento quanto ao controle judicial dos atos executivos:

Art. 1ำ O Governo Provisório exercerá discricionariamente, em toda sua plenitude, as funções e atribuições, não só do Poder Executivo, como tambem do Poder Legislativo, até que, eleita a Assembléia Constituinte, estabeleça esta a reorganização constitucional do país; [...] Art. 5o Ficam suspensas as garantias constitucionais e excluída a apreciação judicial dos atos do atos do Governo Provisório ou dos interventores federais, praticados na conformidade da presente lei ou de suas modificações ulteriores.

A organização administrativa federal foi bastante impactada sendo criadas algumas entidades autárquicas que regulavam a produção e o comércio de alguns produtos, bem como estruturavam programas visando direcionar atividades econômicas. De certa forma, o governo de Getulio Vargas iniciou um caminho que parecia levar a Brasil ao modelo de Estado Administrativo.

Veja-se que em 1o de junho de 1933 Getulio Vargas criou o Instituto do Açúcar e do Álcool - IAA, para regular a agricultura canavieira, controlando a produção, o comércio, a exportação e os preços do açúcar e do álcool de cana. Ainda em 1933 foi criado o Departamento Nacional do Café (posteriormente, transformado no IBC). Em 1938 criou-se o

${ }^{43}$ McCRAW, Thomas, et al. Prophets of Regulation: Charles Francis Adams, Louis D. Brandeis, James M. Landis, Alfred E. Kahn. Cambridge, MA: Belknap Press of Harvard University Press, 1984, p.56.

3 JOURNAL OF INSTITUTIONAL STUDIES 1 (2017) 
Instituto Nacional do Mate - INM, e avançou-se no controle estatal das atividades ligadas ao petróleo e combustíveis, por meio da criação do Conselho Nacional do Petróleo. Em 1941, foi criado o Instituto Nacional do Pinho - INP e, no ano seguinte, foram instituídas as Comissões Executivas de Frutas, do Leite, de Produtos da Mandioca e da Pesca.

Malgrado a criação dessas entidades autárquicas, de fato permaneceu o modelo de forte centralização do poder nas mãos do Chefe do Poder Executivo. O Governo Provisório durou quatro anos (1930-1934), sendo promulgada a Constituição Federal de 1934. O Governo Constitucional durou pouco, até o ano de 1937, quando foi editada a nova Carta.

No texto original de 1937 assim foi posta a competência do Chefe do Poder Executivo que, valendo-se de conceitos jurídicos indeterminados, lançou os mecanismos de limitação do controle dos seus atos administrativos. ${ }^{44}$

Outras disposições constitucionais apontam para o grande espaço que se abriu para a atuação administrativa com base nas escolhas pessoais - $\mathrm{e}$ não sindicáveis - do Chefe do Poder Executivo. ${ }^{45}$

44 "Art 73 - o Presidente da República, autoridade suprema do Estado, coordena a atividade dos órgãos representativos, de grau superior, dirige a política interna e externa, promove ou orienta a política legislativa de interesse nacional, e superintende a administração do País. Art 74 - Compete privativamente ao Presidente da República: a) sancionar, promulgar e fazer publicar as leis e expedir decretos e regulamentos para a sua execução; b) expedir decretos-leis, nos termos dos arts. 12 e 13; [...] Art 96 - Só por maioria absoluta de votos da totalidade dos seus Juízes poderão os Tribunais declarar a inconstitucionalidade de lei ou de ato do Presidente da República. Parágrafo único No caso de ser declarada a inconstitucionalidade de uma lei que, a juízo do Presidente da República, seja necessária ao bem-estar do povo, à promoção ou defesa de interesse nacional de alta monta, poderá o Presidente da República submetê-la novamente ao exame do Parlamento: se este a confirmar por dois terços de votos em cada uma das Câmaras, ficará sem efeito a decisão do Tribunal."

45 "Art 166 - Em caso de ameaça externa ou iminência de perturbações internas ou existências de concerto, plano ou conspiração, tendente a perturbar a paz pública ou pôr em perigo a estrutura das instituições, a segurança do Estado ou dos cidadãos, poderá o Presidente da República declarar em todo o território do Pais, ou na porção do território particularmente ameaçado, o estado de emergência. Desde que se torne necessário o emprego das forças armadas para a defesa do Estado, o Presidente da República declarará em todo o território nacional ou em parte dele, o estado de guerra. Parágrafo único - Para nenhum desses atos será necessária a autorização do Parlamento nacional, nem este poderá suspender o estado de emergência ou o estado de guerra declarado pelo Presidente da República. [...] Art 169 - O Presidente da 
O Estado Novo vigorou entre 1937 e 1945, sendo promulgada nova Constituição Federal em 1946, trazendo avanços na contenção do Poder Executivo, até ser completamente descaracterizada por meio de atos decorrentes do golpe militar de 1964. A título exemplificativo, em 1965 foi editado o Ato Institucional $\mathrm{n}^{\mathrm{0}}$ 2, de 27 de outubro, em que foram excluídos da apreciação judicial: "I - os atos praticados pelo Comando Supremo da Revolução e pelo Governo federal".

Diante desse quadro de absoluto espaço para o exercício da discricionariedade administrativa na execução de tarefas administrativas, insindicável pelo Poder Judiciário, adveio o marco legal da organização administrativa brasileira pelo Decreto-Lei $n^{0}$ 200/67. Contudo, a estrutura posta manteve a ampla centralização administrativa nas mãos do Chefe do Poder Executivo federal. Com efeito, ainda que nessa norma a Administração Pública aparecesse como sendo centralizada ou direta, e descentralizada ou indireta (autarquias, fundações, empresas públicas e sociedades de economia mista), a última palavra competiria, sempre, ao Chefe do Poder Executivo: “Art. 170. O Presidente da República, por motivo relevante de interêsse público, poderá avocar e decidir qualquer assunto na esfera da Administração Federal."

República, durante o estado de emergência, e se o exigirem as circunstâncias, pedirá à Câmara ou ao Conselho Federal a suspensão das imunidades de qualquer dos seus membros que se haja envolvido no concerto, plano ou conspiração contra a estrutura das instituições, e segurança do Estado ou dos cidadãos. § $1^{\text {o }}$ - Caso a Câmara ou o Conselho Federal não resolva em doze horas ou recuse a licença, o Presidente, se, a seu juízo, se tornar indispensável a medida, poderá deter os membros de uma ou de outro, implicados no concerto, plano ou conspiração, e poderá igualmente fazê-lo, sob a sua responsabilidade, e independentemente de comunicação a qualquer das Câmaras, se a detenção for de manifesta urgência. $\S 2^{\circ}$ - Em todos esses casos o pronunciamento da Câmara dos Deputados só se fará após a terminação do estado de emergência. Art 170 - Durante o estado de emergência ou o estado de guerra, dos atos praticados em virtude deles não poderão conhecer os Juízes e Tribunais. Art 171 - Na vigência do estado de guerra deixará de vigorar a Constituição nas partes indicadas pelo Presidente da República. [...] Art 185 - O julgamento das causas em curso na extinta Justiça Federal e no atual Supremo Tribunal Federal será regulado por decreto especial que prescreverá, do modo mais conveniente ao rápido andamento dos processos, o regime transitório entre a antiga e a nova organização judiciária estabelecida nesta Constituição. Art 186 - É declarado em todo o Pais o estado de emergência." 


\section{1995: Plano Diretor da Reforma do Estado e bUSCA PELO ESTADO ADMINISTRATIVO}

O quadro de forte centralização do poder nas mãos do Chefe do Poder Executivo só foi modestamente mitigado no Brasil com a implantação, parcial, do modelo de agências reguladoras. Esse modelo surgiu na década de 90 do século passado, sendo implantado em um momento de reestruturação do papel do Estado em relação à sua atuação na economia. Ocorreu durante o governo do Presidente Fernando Henrique Cardoso, sob a direção de Luiz Carlos Bresser Pereira. ${ }^{46}$

Naquela fase, a segregação de competências entre a Administração Pública direta e a indireta para a regulação autônoma de utilidades públicas estratégicas (telefonia, energia elétrica etc.), apresentou-se como sendo fundamental para: (i) criar um ambiente propício à segurança jurídica dos contratos com o Estado e atração de capital privado (notadamente estrangeiro); e (ii) descentralizar a governança estatal sob temas complexos e preponderantemente técnicos, emprestando-lhes certa previsibilidade e tornando-as menos suscetíveis aos embates e interesses políticos/partidários típicos das rotinas do Congresso Nacional.

Essas novas autarquias surgiram a partir da eleição do Presidente Fernando Henrique Cardoso, em 1995, quando houve uma intensificação nas privatizações, sendo o programa de desestatizações apontado como sendo um dos principais instrumentos do Plano Diretor da Reforma do Aparelho do Estado.

Esse plano previu, dentre outras questões, a criação de agências autônomas, vinculadas às atividades de Estado. Essas agências autônomas surgiriam da análise das missões dos órgãos e entidades governamentais, identificando superposições, inadequação de funções e possibilidades de descentralização visando, segundo o plano, dotar o Estado de uma estrutura organizacional moderna, ágil e permeável à participação popular.

Ao se referir às agências autônomas, o Plano Diretor da Reforma do

${ }^{46} \mathrm{O}$ desenvolvimento do modelo de agências, desenvolvido pela equipe chefiada pelo então Ministro Bresser Pereira, do Governo Fernando Henrique Cardoso, pode ser conferido em suas obras BRESSER PEREIRA, Luiz Carlos. Da Administração Pública Burocrática à Gerencial. In: Luiz Carlos Bresser Pereira; Peter Kevin Spink (Orgs.).

Reforma do Estado e Administração Pública Gerencial. Rio de Janeiro, RJ: FGV, 1998; e BRESSER PEREIRA, Luiz Carlos. Construindo o Estado Republicano: Democracia e Reforma da Gestão Pública. Rio de Janeiro, RJ: FGV, 2009. 
Aparelho do Estado estabeleceu que a responsabilização por resultados e a consequente autonomia de gestão inspiraram a formulação desse projeto. O objetivo era a transformação de autarquias e de fundações que exerciam atividades exclusivas do Estado, em agências autônomas, com foco na modernização da gestão.

O Plano previa que o projeto das agências autônomas desenvolver-seia em duas dimensões. Em primeiro lugar, seriam elaborados os instrumentos legais necessários à viabilização das transformações pretendidas, e um levantamento visando superar os obstáculos na legislação, normas e regulações existentes. Em paralelo, seriam aplicadas as novas abordagens em algumas autarquias selecionadas, que se transformariam em laboratórios de experimentação.

Essa transformação de entidades estatais em agências, no formato apresentado pelo Plano Diretor, de fato não ocorreu. Ao que parece, o modelo de "Administração Gerencial" que o Plano Diretor apresentou, previsto para ser aplicado em praticamente todas as áreas da Administração Pública federal, pretendia seguir modelo próximo ao sistema norte-americano de agências:

$\mathrm{Na}$ administração pública gerencial a estratégia volta-se (1) para a definição precisa dos objetivos que o administrador público deverá atingir em sua unidade, (2) para a garantia de autonomia do administrador na gestão dos recursos humanos, materiais e financeiros que lhe forem colocados à disposição para que possa atingir os objetivos contratados, e (3) para o controle ou cobrança a posteriori dos resultados. [...] Em suma, afirma- se que a administração pública deve ser permeável à maior participação dos agentes privados e/ou das organizações da sociedade civil e deslocar a ênfase dos procedimentos (meios) para os resultados (fins).

Quando o Plano Diretor trata dos objetivos para as denominadas "atividades exclusivas" do Estado, propõe, inclusive, a transformação das autarquias e fundações em agências, e que os seus dirigentes sejam indicados por critérios rigorosamente profissionais:

Transformar as autarquias e fundações que possuem poder de Estado em agências autônomas, administradas segundo um contrato de gestão; o dirigente escolhido pelo Ministro segundo critérios rigorosamente profissionais, mas não necessariamente de dentro do Estado, terá ampla liberdade para administrar os recursos humanos, materiais e financeiros colocados à sua disposição, desde que atinja os objetivos qualitativos e quantitativos (indicadores de desempenho) previamente acordados. 
Quanto à criação das agências autônomas, o Plano Diretor previu que haveria obstáculos na legislação para a criação desse novo modelo burocrático:

A responsabilização por resultados e a consequente autonomia de gestão inspiraram a formulação deste projeto, que tem como objetivo a transformação de autarquias e de fundações que exerçam atividades exclusivas do Estado, em agências autônomas, com foco na modernização da gestão. O Projeto das Agências Autônomas desenvolver-se-á em duas dimensões. Em primeiro lugar, serão elaborados os instrumentos legais necessários à viabilização das transformações pretendidas, e um levantamento visando superar os obstáculos na legislação, normas e regulações existentes. Em paralelo, serão aplicadas as novas abordagens em algumas autarquias selecionadas, que se transformarão em laboratórios de experimentação.

Pelo que se pode depreender da análise do modelo de agências norteamericano e do Plano Diretor da Reforma do Estado brasileiro, de 1995, o objetivo da administração do Presidente Fernando Henrique Cardoso, sob o comando do Ministro Bresser Pereira, era transformar as autarquias e fundações, isto é, a administração pública indireta em agências próximas ao sistema estadunidense de Estado Administrativo, de certa forma "esvaziando" a forte centralização de poder nas mãos da Administração Direta.

Cumpre destacar que o projeto aprovado consistia em que fosse firmado um contrato de gestão pelo qual o dirigente escolhido pelo Ministro, segundo critérios rigorosamente profissionais, teria ampla liberdade para administrar os recursos humanos, materiais e financeiros da agência. As agências teriam objetivos qualitativos e quantitativos que seriam medidos por indicadores de desempenho.

Se esse projeto fosse realmente implementado haveria, de fato, uma grande transformação da máquina estatal brasileira, aproximando-se do modelo de Estado Administrativo norte-americano. O sistema atual, salvo poucas situações, ainda segue e está vinculado ao velho modelo clientelista, em que prevalece o interesse político ou partidário em detrimento das decisões planejadas, tomadas com base técnica, ausência de suporte empírico e transparência na demonstração dos custos e benefícios das medidas burocráticas.

$\mathrm{O}$ atual sistema presidencialista brasileiro propicia uma forte concentração de poderes nas mãos do Chefe do Poder Executivo, com atuação voltada, em grande parte, para as alianças políticas, para os resultados das urnas, o que contribui fortemente para a corrupção. 
Diante das características dessas novas autarquias brasileiras, e se não há dúvidas de que o modelo de agencificação nacional está próximo ao Estado Administrativo dos Estados Unidos da América, ${ }^{47}$ pode-se concluir que apenas uma pequena - e modesta - fração do modelo de agencificação norte-americano chegou à Administração Pública brasileira. Foram criadas dez autarquias especiais que, diferenciando-se das demais autarquias "comuns", têm órgão colegiado, recursos orçamentários decorrentes de taxas de regulação, ${ }^{48}$ função quasenormativa, quase-judicial e independência decisória. Os dirigentes receberam mandato fixo, que, formalmente, os protegem quanto à demissão imotivada pelo Presidente da República.

Trazendo novidade aos direitos constitucional e administrativo brasileiro, as agências nacionais foram criadas sob a natureza autárquica especial, com as seguintes características: órgão colegiado, mandato fixo e em prazos escalonados para seus dirigentes, autonomia administrativa e decisória, congregando funções executivas, normativas e judicantes.

A introdução dessas agências, na estrutura burocrática nacional de viés weberiano ${ }^{49}$, gerou - e ainda gera - polêmicas. Há questionamento na esfera política, notadamente, quanto à sua legitimidade democrática. $\mathrm{O}$ mesmo ocorre na seara jurídica, envolvendo vários questionamentos sobre a sua juridicidade.

Em linhas gerais, discute-se a constitucionalidade da implantação do modelo quanto: (i) à ofensa ao princípio tripartite da separação de poderes; (ii) à ausência de juridicidade na delegação de funções normativas, sob o argumento de serem privativas do Poder Legislativo, e, (iii) o malferimento do princípio da hierarquia e da unidade governamental, relativamente à função do Chefe do Poder Executivo.

${ }^{47}$ A estrutura detalhada do sistema regulatório norte-americano pode ser conferido em CASS, Ronald, et al. Administrative Law: cases and materials. $6^{\text {a }}$ ed. New York, NY:

Wolters Kluwer Law \& Business, 2011.

${ }^{48}$ Em que pese o contingenciamento de recursos (retardamento ou inexecução de parte da programação de despesa prevista na Lei Orçamentária) que essas autarquias vêm experimentando nos últimos anos.

${ }^{49}$ Burocracia, no sentido estruturado por Max Weber, contrapondo-se à ideia de patrimonialismo. Cf. WEBER, Max. Economia e Sociedade: Fundamentos da Sociologia Compreensiva, Vol. 2. Trad. Regis Barbosa e Karen Elsabe Barbosa. São Paulo, SP: Imprensa Oficial do Estado de São Paulo, 2004, p. 199. Título original: Wirtschaft und Gesellschaft: Grundriss der verstehenden Soziologie. Sobre o debate norteamericano acerca das características atuais da burocracia federal, cf. SCHUCK, Peter. Why Government Fails so Often: And How It Can Do Better. Princeton, NJ: Princeton University Press, 2014, p. 307 e ss. 


\section{CONCLUSÃO}

A governança brasileira, durante quase toda a república, seguiu o modelo francês: centralização e hierarquia, com poder concentrado nas mãos do Chefe do Poder Executivo (Executivo Unitário).

Ao contrário, no modelo norte-americano o surgimento do direito administrativo (administrative law) está relacionado às agências, sejam elas executivas, regulatórias ou empresarias, independentes ou não configurando um Estado Administrativo. Levando-se em conta o ambiente em que surgiu, o desenvolvimento dos modelos adotados que formataram o sistema de agencificação, os conflitos, questionamentos e teses, nos Estados Unidos da América e no Brasil, verifica-se que os desenhos burocráticos são diferentes.

As agências surgiram, nos Estados Unidos da América, no século XIX e apenas em alguns estados da federação. $O$ objetivo era regular o transporte ferroviário por meio de experts, então a mais importante e complexa atividade econômica na fase agrária. Com a proibição da regulação do setor ferroviário por agências estaduais surgiu a primeira agência reguladora federal, em 1887.

O movimento progressista ergueu a bandeira da agencificação contra o cenário caótico por que passava o governo no final do século XIXI e início do século XX. O movimento se propagou pela classe média localizada em áreas urbanas chocados com a corrupção e fraudes no campo político. A solução para esses problemas seria a criação de agências, de modo que as decisões sobre o controle de determinadas atividades industriais fossem decididas por experts, de forma racional e livres das pressões partidárias no formato conhecido como spoil system.

Com esses antecedentes, opositores e defensores, o modelo de regulação estatal norte-americano vem sendo mantido desde o século XIX até os dias atuais com o respaldo da Suprema Corte.

$\mathrm{O}$ modelo estadunidense de agências, no estágio atual, privilegia a ocupação de cargos por experts, a participação popular (public participation), a transparência nos procedimentos e nas decisões (transparency of government action) e com sistema de garantias processuais, próximo ao modelo jurisdicional (judicialized procedures for individual determinations)..$^{50}$

As ações de uma agência devem estar de acordo com o detalhamento

${ }^{50}$ MASHAW, Jerry. Creating the Administrative Constitution: the lost one hundred years of American administrative law. New Haven, CT: Yale University Press, 2012, p. 288. 
contido na lei de criação. ${ }^{51}$ Quando há um questionamento sobre os seus atos, os tribunais examinam os dados em recurso de apelação (appeal) de acordo com standards previstos na lei que outorgou competência à agência, geralmente, mantendo a escolha regulatória (princípio da deferência).

A maioria das leis de criação das agências possui termos vagos e abertos (intelligle principles), permitindo à agência certa flexibilidade e, até mesmo, discrição ${ }^{52}$ para criar as suas próprias regras e procedimentos.

O Brasil ensaiou uma aproximação com o Estado Administrativo nas décadas de 30 e 40 com a criação de certas autarquias reguladoras (IAA, IBC etc.) e somente quando da edição do Plano Diretor da Reforma do Aparelho do Estado, em 1995, apresentou-se um desenho próximo ao sistema norte-americano para reestruturar a Administração Pública.

Na prática, o Plano não foi adotado. Apenas, inicialmente em nove entidades autárquicas, as quais se juntou a Agência Nacional de Aviação - ANAC, em 2005, durante o Governo do Presidente Lula, adotou-se parte do esquema norte-americano (mandato, outorga de competência normativa a partir de expressões vagas e amplas, além de autonomia decisória).

Em suma, a burocracia brasileira, mesmo com o advento das agências reguladoras (autarquias especiais), é diferente do sistema burocrático estadunidense e não pode ser caracterizado como sendo um Estado Administrativo. Os dois modelos partem de estruturas de governabilidade e de governança completamente diferentes. Apenas uma pequena parte do desenho institucional, que atribui mandato aos dirigentes e autonomia decisória à agência reguladora, foi copiado do modelo americano pelo Brasil.

Conclusivamente, trata-se de uma reprodução do Estado Administrativo estadunidense, apenas parcial, em que o modelo nacional - federativo e presidencialista - passou a adotar o sistema de regulação descentralizada, com algum grau de autonomia e independência do governo central, em delegações de serviços públicos e algumas atividades privadas de interesse público próximo ao modelo das public utilities.

${ }^{51}$ Cf. CROLEY. Steven. Regulation and Public Interest: the Possibility of Good

Regulatory Government. Princeton, NJ: Princeton University Press, 2008, p. 81.

52 Para conferir críticas à discrição das agências, cf. EPSTEIN, Richard. Simple Rules

for a Complex World. Cambridge, MA: Harvard University Press, 1995, p. 37 e ss. 


\section{REFERÊNCIAS}

BERNSTEIN, Marver. Regulating Business by Independent

Commission. Princeton, NJ: Princeton University Press, 1955.

BRESSER PEREIRA, Luiz Carlos. Luiz Carlos. Construindo o Estado Republicano: Democracia e Reforma da Gestão Pública. Rio de Janeiro, RJ: FGV, 2009.

. Da Administração Pública Burocrática à Gerencial. In: Luiz Carlos Bresser Pereira; Peter Kevin Spink (Orgs.). Reforma do Estado e Administração Pública Gerencial. Rio de Janeiro, RJ: FGV, 1998.

BREYER, Stephen. Regulation and its Reform. Cambridge, MA:

Harvard University Press, 1982.

CASS, Ronald, et al. Administrative Law: cases and materials. $6^{\underline{a}}$ ed. New York, NY: Wolters Kluwer Law \& Business, 2011.

CROLEY. Steven. Regulation and Public Interest: the Possibility of Good Regulatory Government. Princeton, NJ: Princeton University Press, 2008.

CUSHMAN, Robert. The Independent Regulatory Commissions. New York, NY: Octagon Books, 1972.

DUDLEY, Susan; BRITO, Jerry. Regulation: a Primer. $2^{a}$ ed. Arlington, VA: The George Washington University, 2012.

EPSTEIN, Richard. Simple Rules for a Complex World. Cambridge, MA: Harvard University Press, 1995. 
LANDIS, James. Report on regulatory agencies to the president-elect: a report submitted to Sen. John F. Kennedy - December 21, 1960. New Orleans, LA: Quid Pro Books, 2014.

. The Administrative Process. New Haven, CT: Yale Univesity Press, 1938.

LAWSON, Gary. Limited Government, Unlimited Administration: Is it possible to restore Constitution? First Washington, DC: Heritage Foundation, 2009.

MASHAW, Jerry. Creating the Administrative Constitution: the lost one hundred years of American administrative law. New Haven, CT: Yale University Press, 2012.

McCRAW, Thomas, et al. Prophets of Regulation: Charles Francis Adams, Louis D. Brandeis, James M. Landis, Alfred E. Kahn. Cambridge, MA: Belknap Press of Harvard University Press, 1984.

MOSHER. Frederick. Basic documents of American public administration: 1776-1950. New York, NY: Holmes \& Meier Publishers, Inc. 1976.

POSNER, Richard. Theories of Economic Regulation. The Bell Journal of Economics and Management Science, Vol. 5, 2, 1974.

PRIEST, George. The Origins of Utility Regulation and the "Theories of Regulation" Debate. Journal of Law \& Economics, Vol. 36, 1, 1993.

REGO, Vicente Pereira do. Elementos de Direito Administrativo Brasileiro. Recife, PE: Typographia Universal, 1857.

RIBAS, Antonio Joaquim. Direito Administrativo Brasileiro. Rio de Janeiro, RJ: F.L. Pinto \& C., Livreiros-Editores, 1866. 
SCHUCK, Peter. Why Government Fails so Often: And How It Can Do Better. Princeton, NJ: Princeton University Press, 2014.

SKOWRONEK, Stephen. Building a New American State: the Expansion of National Administrative Capacities, 1877-1920. New York, NY: Cambridge University Press, 1982.

STIGLER, George. The Theory of Economic Regulation. The Bell Journal of Economics and Management Science, Vol. 2, 1, 1971

URUGUAY, Paulino José Soares de Souza, Visconde do. Ensaio sobre o Direito Administrativo. Rio de Janeiro, RJ: Typographia Nacional, 1862.

VEIGA CABRAL, Prudêncio Giraldes Tavares da. Direito Administrativo Brasileiro. Rio de Janeiro, RJ: Laemmert, 1859

WEBER, Max. Economia e Sociedade: Fundamentos da Sociologia Compreensiva, Vol. 2. Trad. Regis Barbosa e Karen Elsabe Barbosa. São Paulo, SP: Imprensa Oficial do Estado de São Paulo, 2004.

Separação de Poderes, Executivo Unitário e Estado Administrativo no Brasil Separation of Powers, Unitary Executive, and the Administrative State in Brazil

Submetido em: 2017-05-18

Aceito em: 2017-07-29 